\title{
The Role of DNA Damage Response in Dysbiosis-Induced Colorectal Cancer
}

\author{
Antonio Rivas-Domínguez (D), Nuria Pastor, Laura Martínez-López, Julia Colón-Pérez, Beatriz Bermúdez * \\ and Manuel Luis Orta *
}

Citation: Rivas-Domínguez, A.;

Pastor, N.; Martínez-López, L.;

Colón-Pérez, J.; Bermúdez, B.; Orta,

M.L. The Role of DNA Damage

Response in Dysbiosis-Induced

Colorectal Cancer. Cells 2021, 10, 1934.

https://doi.org/10.3390/

cells10081934

Academic Editor: George Iliakis

Received: 29 June 2021

Accepted: 23 July 2021

Published: 29 July 2021

Publisher's Note: MDPI stays neutral with regard to jurisdictional claims in published maps and institutional affiliations.

Copyright: (c) 2021 by the authors. Licensee MDPI, Basel, Switzerland. This article is an open access article distributed under the terms and conditions of the Creative Commons Attribution (CC BY) license (https:// creativecommons.org/licenses/by/ $4.0 /)$.
Department of Cell Biology, Faculty of Biology, University of Seville, Av. Reina Mercedes s/n, 41012 Seville, Spain; ardominguez@us.es (A.R.-D.); npastor@us.es (N.P.); lmlopez@us.es (L.M.-L.); colonperezjulia@gmail.com (J.C.-P.)

* Correspondence: bbermudez@us.es (B.B.); morta2@us.es (M.L.O.)

Abstract: The high incidence of colorectal cancer (CRC) in developed countries indicates a predominant role of the environment as a causative factor. Natural gut microbiota provides multiple benefits to humans. Dysbiosis is characterized by an unbalanced microbiota and causes intestinal damage and inflammation. The latter is a common denominator in many cancers including CRC. Indeed, in an inflammation scenario, cellular growth is promoted and immune cells release Reactive Oxygen Species (ROS) and Reactive Nitrogen Species (RNS), which cause DNA damage. Apart from that, many metabolites from the diet are converted into DNA damaging agents by microbiota and some bacteria deliver DNA damaging toxins in dysbiosis conditions as well. The interactions between diet, microbiota, inflammation, and CRC are not the result of a straightforward relationship, but rather a network of multifactorial interactions that deserve deep consideration, as their consequences are not yet fully elucidated. In this paper, we will review the influence of dysbiosis in the induction of DNA damage and CRC.

Keywords: DNA damage; microbiota; nutrition; ROS; bacterial toxins; inflammation

\section{Human Microbiota}

Microbiota is defined as the group of microorganisms that naturally inhabit the body of pluricellular organisms. This term includes a highly variable and complex community of fungi, viruses and bacteria that occupies specific niches in healthy organisms [1,2]. In the human body, the number of microorganisms is approximately the same as that of human cells, which is indicative of their significance in human biology $[3,4]$.

Microbiota plays a transcendental role in physiological functions. This community fulfills metabolic, neuronal and immune requirements including the establishment of a protective barrier. Nevertheless, in dysbiosis conditions, it is not that the number of microorganisms may decrease but that the diversity of colonizers changes, with a major impact on homeostasis. This situation can contribute to the development of autoimmune, or inflammatory diseases and cancer [4-6].

The term cancer includes a group of diseases characterized by uncontrolled cell proliferation. Its development depends not only on genetic predisposition but also on environmental factors. In this particular point, dysbiosis might play important roles in carcinogenesis and influence their therapy [7-9].

Recently, several studies have reported that a direct secretion of enzymes or molecules from microbiota can influence the activation of NFKB (nuclear factor kappa-light-chainenhancer of activated B cells), apoptosis pathways or cytoskeleton reorganization. Moreover, chemically modified nutrients from diet act as microbiota modulators boosting ROS/RNS production, toxins and the onset of CRC process [10-12].

Here, we will review the incidence of gut bacterial dysbiosis in CRC development as well as the mechanisms involved, with special emphasis on those that cause DNA damage. 


\section{DNA Damage and Cancer, Old Friends}

A well-known feature of cancer cells is genomic instability. Indeed, DNA damage is responsible for point mutations or chromosome rearrangements frequently found in transformed cells. Chronic inflammation conditions, as those involved in dysbiosis, may promote environmental conditions that favor cancer development through induction of DNA damage [13-15].

DNA can be damaged by endogenous or exogenous sources. Endogenous sources include ROS/RNS, toxic products from cellular metabolism or disturbances in DNA replication, i.e., DNA replication-transcription conflicts. On the other hand, ionizing radiation, UV light and many toxic chemicals used in therapy are exogenous threats to DNA integrity.

DNA Single-Strand Breaks (SSBs) or base damage can be easily found in cells spontaneously as a consequence of the action of ROS and RNS. In this sense, a Base Excision Repair mechanism (BER) can restore the original DNA sequence $[13,16]$. In the first step of this process, damaged bases are recognized and excised by DNA glycosylases. Monofunctional DNA glycosylases such as Uracil DNA Glycosylase (UNG) create only an abasic site. However, bifunctional glycosylases, such as OGG1, also create a nick on the $3^{\prime}$ side of the abasic site [16]. The resulting apurinic/apyrimidinic (AP) site or the nicked DNA are the targets for AP endonuclease (AP-1), which breaks the phosphodiester bond to create an SSB [16]. Normally Pol $\beta$ refills the gaps and nicks are resealed by DNA ligase 1 or ligase 3 [16].

The relationship between BER and Poly (ADP-ribose) polymerase-1 (PARP-1) has been largely discussed. PARP-1 is reported to be a sensor of SSBs $[13,16,17]$ that arise either directly or as intermediates of BER [13,16,17]. Indeed SSBs are protected from degradation by PARP-1 which additionally potentiates the recruitment of repair factors [16]. However, the involvement of PARP-1 as a member of BER has resulted in controversy over the years.

The Mismatch Repair (MMR) pathway detects and removes DNA base-pair mismatches and inappropriate nucleotide insertions/deletions (INDELs) that arise during DNA replication. There are two important protein complexes involved in MMR, namely MutS and MutL. MutS has two isoforms; the first (MutS $\alpha$ ) is constituted by MSH2 and MSH6, and the second one (MutS $\beta$ ) by MSH2 and MSH3. MutL presents three isoforms namely MutL $\alpha$ (MLH1/PMS2), MutL $\beta$ (MLH1/MLH2) and MutL $\gamma$ (MLH1/MLH3). It was shown that mutations in one-off MSH2 or MLH1 can affect the entire system [18-20]. Mechanistically, the mismatch is recognized by MutS, then the endonuclease MutL and the exonuclease EXO1 are recruited. Once resection in the appropriated DNA strand is finished, polymerase $\delta$ and DNA ligase I repair the excised region [21,22].

Microsatellite regions are short sequences of 1 to 6 base pairs, repeated in tandem and present all through the genome. Due to their nature, they are especially prone to induce replication errors, which are normally repaired by MMR. In this sense, any inactivating mutation in the MMR genes mentioned above results in a hyper-mutant phenotype known as microsatellite instability (MSI), due to a defective MMR system (dMMR) [20,21,23].

Nucleotide Excision Repair (NER) repairs bulky- or helix distorting-DNA lesions. Depending on how these injuries are detected, NER is classified into Global- (G-NER) or Transcription-Coupled NER (TC-NER). While G-NER is able to recognize lesions all through the genome, TC-NER is initiated by the blocking of RNA polymerases by DNA damage. The subsequent steps are identical in both branches: DNA is then opened, a singlestrand DNA (ssDNA) region of approximately $24-30$ base pairs is generated, subsequently refilled by replication polymerases and ligated by ligase I [24].

The DNA Damage Response (DDR) coordinates the signaling and repair of DoubleStrand Breaks (DSBs) and long stretches of ssDNA with the cell cycle checkpoints [25]. This is carried out by three phosphoinositide 3-kinase (PI3K)-related serine-threonine kinases, namely DNA-dependent protein kinase (DNA-PK), ataxia telangiectasia-mutated kinase (ATM) and ataxia telangiectasia and Rad3-related protein (ATR) $[25,26]$.

ssDNA stretches accumulate when cells suffer replication stress, as intermediates of the NER pathway and after the resection of DSBs. They are detected by ATR, which 
has a predominant role in phosphorylating and activating CHK1. The resulting ATRCHK1 complex mediates various cell responses that include $\mathrm{S}$ and G2/M checkpoints that facilitate DNA repair [27]. Additionally, ATR promotes Homologous Recombination (HR), regulates proper replication initiation and faithful chromosomal segregation $[27,28]$.

The most difficult DNA lesion to repair is a DSB. One single unrepaired DSB can induce cell death when essential gene is affected [13]. The MRE11-RAD50-NBS1 (MRN) complex recognizes the DSB attracting ATM. ATM phosphorylates several proteins that will mediate cell cycle arrest and DNA repair [25]. In this sense, DNA-PK and H2AX histone are phosphorylated and hence activated by ATM [29]. Phosphorylated H2AX $(\gamma-\mathrm{H} 2 \mathrm{AX})$ will recruit more ATM molecules together with DNA repair factors [25].

DSBs are repaired by two major pathways namely HR and Non-Homologous End Joining (NHEJ) [25,30,31]. While the former needs the presence of a homologous sequence (usually a sister chromatid) to faithfully repair a DSB, the latter reseals directly the two broken edges, which sometimes may put in place new mutations $[25,30,31]$. As a consequence, NHEJ is active during all the cell cycles but HR operates mainly during $S$ and G2 phases.

One-ended DSBs are formed by either collision between replication forks and SSBs or after the processing of stalled forks, and are preferentially repaired by HR. However two-ended DSBs can be repaired by both systems [30].

A summary of the main DNA repair pathways is depicted in Figure 1.
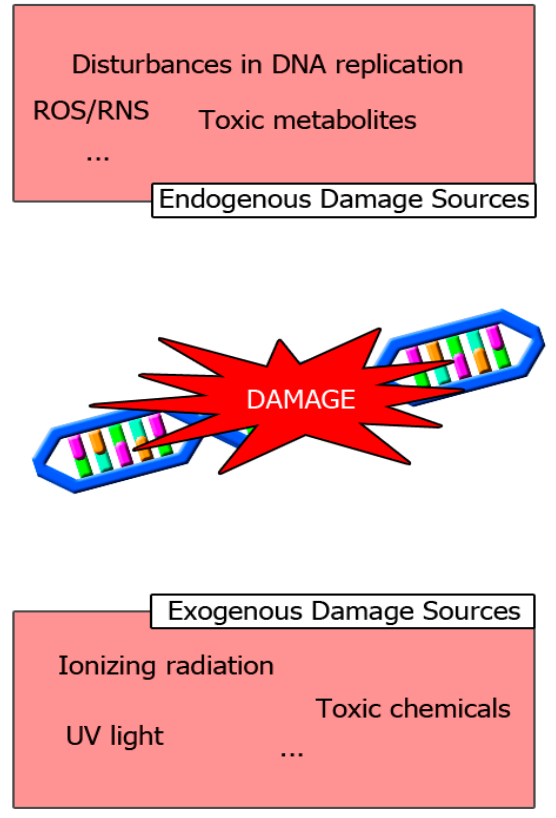

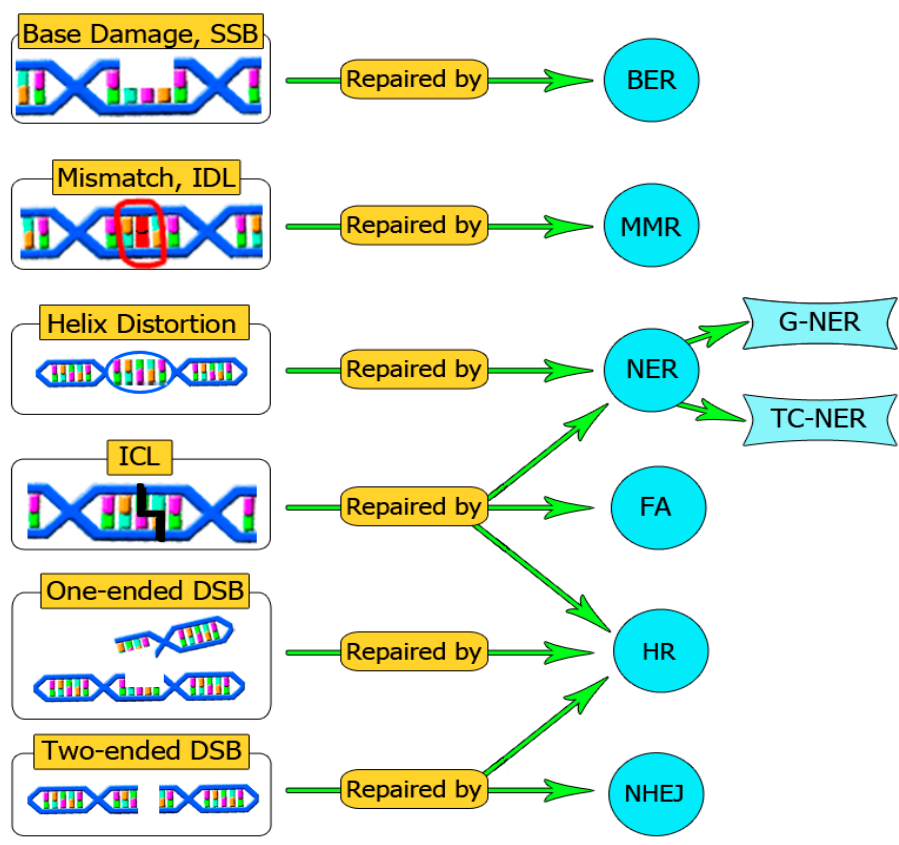

Figure 1. An overview of the main DNA repair systems. DNA can be damaged by exogenous or endogenous agents. A DNA repair defect can be a source of mutations that drive malignancy progression. Sometimes there is a cooperation between different repair pathways to solve complex DNA lesions, such as ICLs. In this sense, a fine-tune cooperation between HR and NER orchestrated by FA is required. SSBs: Single Strand Breaks, BER: Base Excision Repair, IDL: Insertion-Deletion Loops, MMR: Mismatch Repair System, NER: Nucleotide Excision Repair, TC-NER: Transcription coupled-NER, G-NER: Global-NER, DSBs: Double-Strand Breaks, NHEJ: Non-Homologous End Joining, HR: Homologous Recombination, ICL: Interstrand Cross Links, FA: Fanconi Anemia Pathway.

\section{Colorectal Cancer: The Origin}

Although CRC incidence ranks in the third position, and second in terms of mortality worldwide, only a small percentage is attributable to hereditary factors, most of them appear in transitioned countries (4-fold higher) and it is due to an inadequate lifestyle [32]. 


\subsection{The Poisoned Inheritance}

Between $2-5 \%$ of CRC cases have a hereditary component. The Familiar Adenomatous Polyposis (FAP) is present in approximately $1 \%$ of CRC cases and is caused by inherited APC mutations (an early event that facilitates the adenoma-carcinoma transition via WNT activation) $[33,34]$. Other examples of CRC-associated inherited mutations are MUTYH-Associated Polyposis [35], Peutz-Jeghers Syndrome [36] or Serrated Polyposis Syndrome [36]. Of note, hereditary non-polyposis colorectal cancer (HNPCC), also known as Lynch Syndrome (LS), is characterized by mutations that inactivate the MMR pathway and represent $3-4 \%$ of all CRC cases [33,34].

Nevertheless, MMR pathway defects are abundant also in sporadic CRC. Indeed, MLH1 appears inactivated by bi-allelic promoter methylation in 13-16\% of sporadic cancers driving to microsatellite instability (MSI). A defect in MMR has been associated with mutations in key cellular signaling genes, such as BRAF, that has been linked to the onset of CRC $[20,21,23,37]$. Furthermore, a defective MMR was associated with the generation of neoantigens that promote cell survival against the immune system [20].

In other cases, cancer cells are microsatellite-stable but chromosomally unstable (CIN) showing mutations in APC, TP53, KRAS, SMAD4, and PIK3CA (around $84 \%$ of sporadic CRC) $[20,33,38,39]$.

\subsection{Environment Is the Key}

A large number of studies confirm the evidence that environmental factors rather than inherited genetic dysfunctions operate in the development of most CRC cases [40].

A key event in the development of CRC is the tumourigenic atmosphere caused by the loss of the epithelium barrier. The breakage of the epithelial layer favors the contact of bacterial epitopes with immune cells in lamina propria, triggering an exacerbated immune response that perturbs colon homeostasis [41]. As a result, this proinflammatory microenvironment promotes the detachment and mobilization of epithelial cells favoring a dysplasia state [42].

In this aberrant scenario, leukocytes deliver proinflammatory cytokines such as IL$1 \beta$, IL- 6 and TNF- $\alpha$. IL- 6 mediates the release of molecules that promote proliferation, angiogenesis and cell survival [43-45]. IL-1 activates the RAS/MAPK pathway, drives NFKB downstream genes activation, favors autophagy suppression, tumour cell migrationinvasion and aggressiveness [46-49]. Furthermore, IL-1 was associated with a decrease in epithelial E-cadherin, which increases the permeability of the epithelial barrier and favors tumour invasion [50-52].

TNF- $\alpha$ is a key regulator of ROS and RNS signaling. ROS link to several cellular processes as part of signaling pathways. NFKB regulates genes that modulate the amount of ROS and, as a feedback loop, ROS might have a stimulatory or inhibitory role in $\mathrm{NF} \kappa \mathrm{B}$ signaling [53,54]. In a proinflammatory process, ROS levels might degenerate into a toxic effect in neighboring cells, exerting a harmful effect on lipids, proteins, and especially nucleic acids. Long-lasting elevated concentrations of ROS can promote cellular transformation by inducing DNA damage, cell growth, angiogenesis and metastasis $[55,56]$.

High levels of ROS lead to genetic instability and SSBs because of oxidation of pyrimidines and purines and induction of alkali-labile sites [57]. The nucleotide with the highest oxidation potential is guanine, giving rise to 8 -oxo-7,8-dihydro- $2^{\prime}$-deoxyguanosine (8-oxoG). Incorporated 8-oxoG can be repaired either by BER or MMR, but if it is left unrepaired C:G > A:T transversion mutations can appear after replication [58]. BER glycosylases involved in the repair of incorporated 8-oxoG are OGG1 (in 8-oxoG:C base pairs) and MUTYH (in 8-oxoG:A pairs) [16,58]. An excessive number of SSBs, intermediates of BER and MMR, will induce replication- or transcription-coupled DSBs that will finally end in chromosome aberrations and cell transformation [58].

Effector immune cells in organs with chronic inflammation release abnormal levels of nitric oxide (NO), which may alter the physiological function and normal metabolic state, leading to nitrosation of amines [59]. NO is synthesized by several isoforms, being 
inducible NOS (iNOS), which exhibit greater NO output in immune responses [60]. iNOS uses NADPH, L-arginine (L-Arg) and oxygen to generate NO and L-citrulline (L-Cit). When oxygen reacts to the $\mathrm{NO}$ surplus produced during the inflammatory process, generates nitrogen oxides byproducts such as peroxynitrite, $\mathrm{N}_{2} \mathrm{O}_{3}$ and $\mathrm{N}_{2} \mathrm{O}_{4}$, which are powerful nitrosating agents [61].

Indeed, RNS converts secondary amines into activated N-nitrosamine intermediates, which are mutagenic and interact with DNA repair enzymes and transcription factors such as NFKB (see below) [62,63]. Despite the fact that most endogenous nitrosamines are produced by the stomach, different studies have shown nitrosamine formation due to amine production by intestinal bacteria, leading to an increased risk of CRC development [64-66].

Diet-related chronic intestinal inflammation is a proven risk factor for CRC due to colonization by pathogenic microorganisms, which serve to provide pro-tumour immunity, exposure of intestinal cells to their mutagenic metabolites and hence potentiate inflammation. These microorganisms include Colibactin-producing Escherichia coli, enterotoxigenic Bacteroides fragilis and Helicobacter hepaticus among others [67].

It was recently reported that tissue damage or, chronic inflammation induced by such bacteria species, induce oxidative stress and hence 8-oxoG and DSBs [58]. Furthermore, antioxidants such as vitamin $C$ are able to reduce DNA damage and tumourigenesis in this context [58]. In a mouse model for LS, 8-oxoG and DSB resulted higher in MMR defective animals, but antioxidants failed to prevent tumourigenesis [58].

In the next points, we will review more environmental factors involved in CRC development under a DNA damage perspective, such as microbiota-modified metabolites from diet or bacterial toxins.

\section{DNA Damage Induced by Metabolites from Diet}

Nutritional habits seem to modulate microbiota diversity and hence influence colorectal tumourigenesis [68-70]. Healthy diets such as vegan, Mediterranean, or Japanese diets have demonstrated protection against the development of several cancers, besides a reduction in fatality associated with them [71]. It is well accepted that high fiber food protects against CRC, on the other hand, high amounts of red meat, saturated fat and processed food favor its development [40,72-74]. Some bacterial strains present in healthy microbiota are Bacteroidetes (Gram-negative) and Firmicutes (Gram-positive) with lower amounts of Actinobacteria and Verrumicrobia [75]. In contrast, certain strains of Bacteroides fragilis and Escherichia coli (carrying PKs islands), Streptococcus gallolyticus, Enterococcus faecalis and Fusobacterium nucleatum are abundant in CRC patients $[49,67,76]$.

Most nutrients are absorbed in the small intestine; nevertheless, complex carbohydrates, protein-derived compounds and bile acids might reach the large intestine [40]. Once there, microbiota metabolizes those compounds giving rise to "oncometabolites" and "tumour suppressor metabolites" with immune, epigenetic and genotoxic consequences [72]. The proposed mechanisms for these compounds are summarized in Figure 2.

\subsection{Metabolites from Carbohydrates}

Butyrate, propionate and acetate are short-chain fatty acids (SCFA) that result from dietary fiber fermentation by microbiota [77]. These compounds may suppress tumour development through several mechanisms [40]. The main SCFA producers are Bacteroidetes, Clostridium, Eubacteria and Roseburia $[40,74,78]$, which were found to be diminished in CRC patients [78].

The importance of butyrate in the intestinal epithelium is well documented $[40,77]$. Butyrate is the main energy source for enterocytes, increases mucin production and induces the protein expression of claudins and occludines, which participate in the epithelial barrier [77]. Epithelial impermeability is important to avoid the translocation of bacteria or their metabolites to lamina propria, preventing inflammatory episodes. 


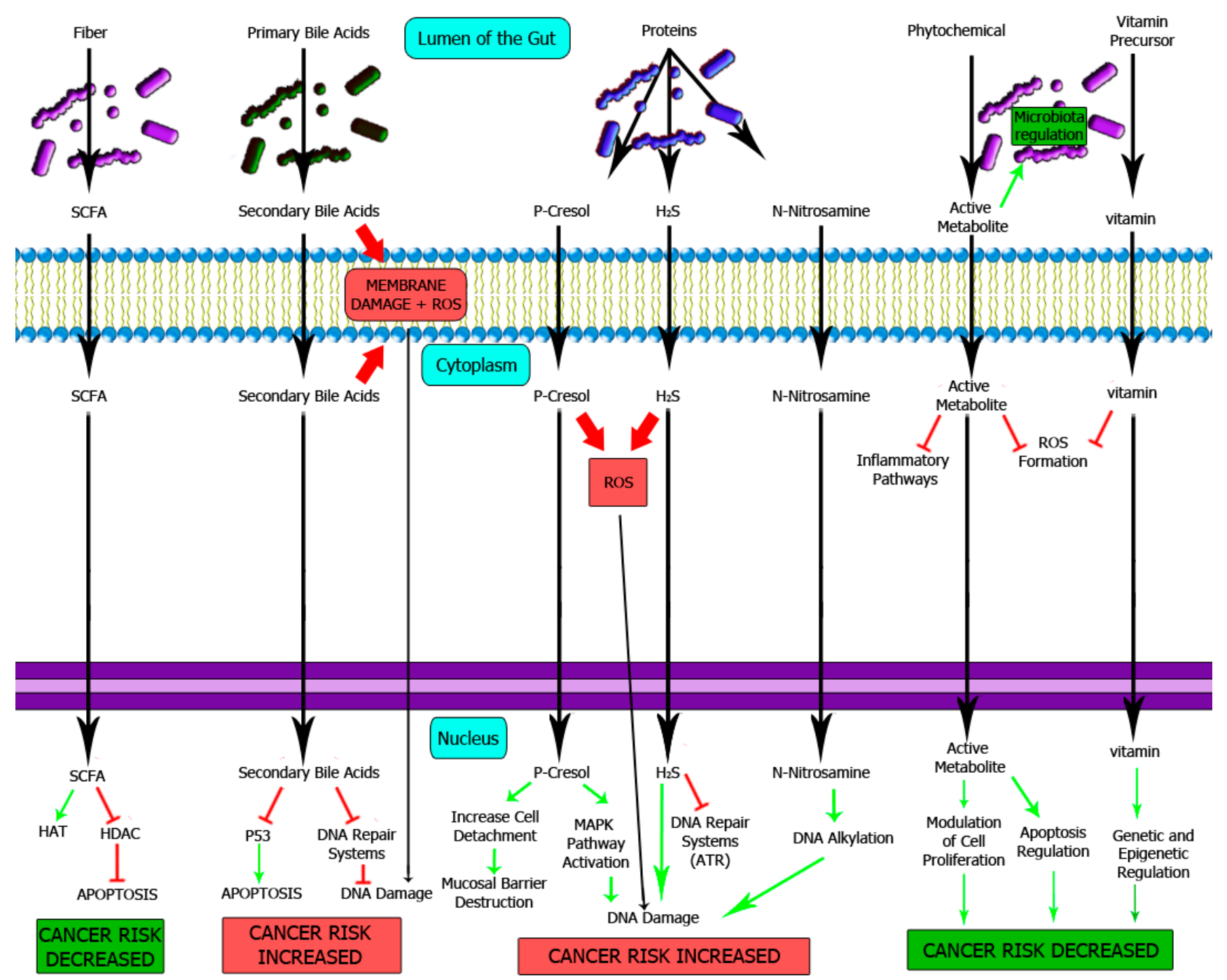

Figure 2. Influence of microbiota-processed nutrients on colon epithelium homeostasis. The importance of normal microbiota has been extensively studied, with a major impact on the protection against CRC. For instance, short-chain fatty acids are tumour suppressor metabolites produced by healthy typical microbiota that protects normal epithelium against neoplasia through an epigenetic mechanism. On the other hand, an excess of oncometabolites such as p-cresol, secondary bile acids or N-nitrosamines will favor mutagenesis and cancer development. SCFA: Short-chain fatty acids, HAT: Histone acetyltransferase, HDAC: Histone deacetylase.

In a healthy colon, butyrate induces cell proliferation due to its role as an energy supplier but also decreases cancer risk through epigenetic regulation [40]. Here, butyrate is metabolized into acetyl-CoA, which stimulates histone acetyltransferase (HAT) activity [79].

On the other hand, CRC is characterized by a high protein expression of HDAC (Histone deacetylase) [40,80], which drives cells to profound epigenetic changes [80]. Due to the Warburg effect, transformed cells prefer glucose to butyrate as energy source. Subsequently, there is an accumulation of butyrate in neoplastic epithelium, which triggers apoptosis via HDAC inhibition $[40,73,79]$.

\subsection{Metabolites from Fat and Bile Acids}

Bile acids are secreted into the small intestine from the gallbladder where they emulsify dietary fats [81]. Primary bile acids such as cholic and chenodeoxycholic, are synthesized by the liver from cholesterol and conjugated with glycine or taurine which increases its emulsifying properties [81]. 
Most of the bile acids are recycled into the enterohepatic circulation. Nevertheless, a residual fraction may remain in the large intestine where it is converted by Bacteroides and Bilophilia into secondary bile acids such as deoxycholic and lithocholic [82].

Deoxycholic and lithocholic cause ROS and membrane damage in enterocytes. Subsequently, arachidonic acid is released and converted by Lipoxygenase (LOX) and Cycloxygenase 2 (COX-2) enzymes into inflammatory prostaglandines and ROS overproduction [9].

Furthermore, secondary bile acids have an inhibitory effect on DNA repair systems, leading to an increment of mutated cells with a marked genetic instability, characterized by the induction of SSB, DSB and aneuploidy [82,83]. DNA repair systems downregulated by secondary bile acids are HR, NER, NHEJ and MMR. Furthermore, levels of ATM are reduced as well as OGG1 and MUTYH glycosylases [82,83].

Additionally, it was reported that deoxycholic acid induces proteasomal degradation of p53 [84] and activates survival and proliferative pathways such as Wnt/ $\beta$-catenin [83], PKC [85] and NFKB [85], which egress apoptosis-resistant clones [82,83].

\subsection{Metabolites from Proteins}

Protein degradation by colon microbiota has been extensively studied $[40,81,86]$. Colon bacteria break down undigested peptides, digestive enzymes, mucin and cell debris from the small intestine $[40,81,86]$. As a result, fatty acids, short peptides and amino acids are generated. However, many toxic compounds are also released such as amines, nitrates, nitrites, N-nitrosamines, hydrogen sulfide $\left(\mathrm{H}_{2} \mathrm{~S}\right)$, p-cresol and ammonia [40]. Protein fermentation by microbiota is higher at the distal part of the large intestine, where these metabolites are found at larger concentrations [86,87].

\subsection{1. p-Cresol}

When aromatic amino acids, such as tyrosine, tryptophan and phenylalanine ferment, a wide variety of phenolic and indolic compounds are generated. For instance, tyrosine fermentation generates $\mathrm{p}$-cresol reaching up to $0.5 \mathrm{mM}$ concentration in human feces $[87,88]$. Most of the p-cresol is absorbed by enterocytes and later on, metabolized by the liver and excreted in urine [86,87].

Andriamihaja and colleagues studied the deleterious effects of millimolar concentrations of p-cresol on the human adenocarcinoma cell line HT-29 Glc ${ }^{-/+}$[87]. They found that $\mathrm{p}$-cresol at $0.8 \mathrm{mM}$ diminished cell proliferation due to an increase in cell detachment and S-phase delay [87]. Potentially, this detachment could implicate the disruption of the epithelial barrier in vivo and causes colon inflammation. P-cresol concentrations above $1.6 \mathrm{mM}$ were genotoxic as measured by the $\gamma$-H2AX foci assay. Additionally, p-cresol had a negative effect on the mitochondrial respiratory chain with subsequent anion superoxide (ROS) production. According to the authors, the observed toxicity is independent of DNA damage induction [87].

Recently, a report strengthens the hypothesis that colon microbiota-derived p-cresol behaves as a genotoxic agent at physiological concentrations [75]. Bacterial cultures from human fecal inoculums were grown with a high tyrosine supplement and supernatants were used to treat HT29 and Caco-2 cells for $24 \mathrm{~h}$. According to the data, p-cresol could serve as a great predictor of genotoxicity in enterocytes. Cell cycle was arrested in $S$ phase at $0.5 \mathrm{mM}$, however, this effect was not evident at higher concentrations [75]. Authors explain that low doses of p-cresol induce tumour growth [89], though; this effect is masked at higher concentrations by DNA damage-induced G0/G1 and G2/M checkpoints [75].

\subsection{2. $\mathrm{H}_{2} \mathrm{~S}$}

Another important residual metabolite from sulfate-reducing bacteria is $\mathrm{H}_{2} \mathrm{~S}[40,81,90]$. Classically this molecule was considered as a toxic molecule, although in recent decades, it is believed that $\mathrm{H}_{2} \mathrm{~S}$ behaves as a signaling molecule in physiological processes such as cell proliferation, apoptosis, inflammation, hypoxia, neuromodulation and cardioprotection [91]. In mammals, the production of $\mathrm{H}_{2} \mathrm{~S}$ results from the enzymatic action of cys- 
tathionine beta-synthase (CBS), cystathionine gamma-lyase (CSE) and 3-mercaptopyruvate sulfurtransferase (3-MST) [91].

Regarding to $\mathrm{CRC}, \mathrm{H}_{2} \mathrm{~S}$ has been described to have pro- and anticancer effects. Endogenously produced $\mathrm{H}_{2} \mathrm{~S}$ or low $\mathrm{H}_{2} \mathrm{~S}$ treatments can maintain or promote cancer growth while high exposures exhibit anticancer effects [92]. Endogenously CBS-produced $\mathrm{H}_{2} \mathrm{~S}$ can promote angiogenesis and maintain cellular bioenergy in colon cancer cells [92]. Furthermore, at $24 \mathrm{~h}$ of exogenous exposure to $50-200 \mu \mathrm{M}$ of $\mathrm{NaHS}$ (a donor of $\mathrm{H}_{2} \mathrm{~S}$ ), can accelerate cell cycle progression by decreasing the levels of p21 and increasing the levels of $\mathrm{S}$ phase cells $[92,93]$. However, relatively high concentrations of exogenous $\mathrm{H}_{2} \mathrm{~S}$ can have a growth-suppressive effect. For instance, $1 \mathrm{mM}$ of $\mathrm{NaHS}$ for 12-24 h upregulates the protein expression of p21 in human colon cancer cells [92,94].

Another main issue is autophagy. Autophagy is a catabolic process that involves the lysosomal digestion and subsequent recycling of internal components [95]. Concerning cancer progression, autophagy has a dual role. Initially, in pre-malignant lesions, autophagy prevents cancer development but if cancer is well-established, autophagy facilitates tumour survival and growth [95]. Recently, it was shown that endogenous levels or exogenous treatments with $\mathrm{H}_{2} \mathrm{~S}$ in several hepatocarcinoma cell lines could present opposite effects on autophagy [96].

In reference to DNA damage induction, $\mathrm{H}_{2} \mathrm{~S}$ was reported to be genotoxic for enterocytes and has been associated with ulcerative colitis and CRC $[40,81,90,97,98] . \mathrm{H}_{2} \mathrm{~S}$, at doses found in human colon $(250 \mu \mathrm{M})$, induced DNA damage to CHO cells [97]. Similar data was found when the HT29-Cl.16E colon cell line was assayed with higher $\mathrm{H}_{2} \mathrm{~S}$ concentrations [97]. In this case a modified alkaline comet assay, in which DNA repair was inhibited by hydroxyurea and a chain terminator (Ara-C) was used [99]. Taken together, a DNA repair defect and the presence of $\mathrm{H}_{2} \mathrm{~S}$ arguably predispose enterocytes to genomic instability in a cancer progression context [97].

Later on, it was reported that $\mathrm{H}_{2} \mathrm{~S}$ induced-DNA damage was based on a free radicals production mechanism [98]. The exposure to $\mathrm{H}_{2} \mathrm{~S}$ rapidly increased the NADPH/NADP ratio through inhibition of mitochondrial respiratory chain in the non-transformed rat intestinal cell line IEC-18 [100,101]. The electron transport chain defect observed could be responsible for the generation of genotoxic free radicals.

Additionally, it was found that $\mathrm{H}_{2} \mathrm{~S}$ induced DNA damage in a colon non-transformed human cell line (FHs $74 \mathrm{Int}$ ) at doses that can be found in large intestine [90]. Doses lower than $500 \mu \mathrm{M}$ were genotoxic and induced changes in gene expression patterns without showing cytotoxic effects. Indeed, pro-inflammatory COX-2 expression was approximately 8-fold upregulated after $30 \mathrm{~min}$ exposure [90]. The expression of several genes related to the DNA damage response was also altered. For instance, GTF2H1, belonging to multimeric transcription factor II H (TFIIH), which is involved in NER, and XRCC6, linked to NHEJ were upregulated within the first $30 \mathrm{~min}$. However, RAD51 (HR) and MLH1 were downregulated after $4 \mathrm{~h}$ exposure [90].

A high protein expression of COX-2 was linked to transformed epithelial cells and activated macrophages in CRC [102,103]. Activation of the NFKB pathway and the subsequent synthesis of proinflammatory cytokines has also been reported in monocytes exposed to $\mathrm{H}_{2} \mathrm{~S}$ [104].

In 2019, Chen and coworkers showed how $\mathrm{H}_{2} \mathrm{~S}$ regulates ATR levels and its phosphorylation [28]. The presented data show how ATR orchestrates the DDR induced by $\mathrm{H}_{2} \mathrm{~S}$. Indeed, cells carrying ATR mutations showed DNA damage after low $\mathrm{H}_{2} \mathrm{~S}$ exposure, and were hypersensitive to higher concentrations [28]. However, a complex regulatory mechanism between ATR and $\mathrm{H}_{2} \mathrm{~S}$ was postulated [28]. First, ATR inversely regulates enzymes involved in $\mathrm{H}_{2} \mathrm{~S}$ synthesis and hence $\mathrm{H}_{2} \mathrm{~S}$ concentration. Second, high $\mathrm{H}_{2} \mathrm{~S}$ concentrations suppress ATR phosphorylation at serine 435 (ATR-pS435) while low levels increase it [28]. Of interest, PKA-mediated ATR phosphorylation at serine 435 is required to promote NER and reduces mutagenesis via ATR-XPA complex formation [105]. 


\subsubsection{N-Nitrosamines}

$\mathrm{N}$-nitrosamines are organic molecules derived from protein fermentation. These compounds result from the combination of amines and nitrates. N-nitrosomorpholine, $\mathrm{N}$-nitrosodimethylamine and $\mathrm{N}$-nitrosopyrrolidine are the most relevant compounds in this group [40].

$\mathrm{N}$-nitrosamines require metabolic activation by cytochrome P450 to wield their carcinogenic effect $[106,107]$. Then, nitrosamines are $\alpha$ - and $\beta$-hydroxylated giving rise to end products that can finally alkylate nucleophilic sites of DNA. Consequently, mutagenic alkali-labile adducts are generated, leading to abasic site formation and DNA strand breaks that can be detected by alkaline comet assay [106-108].

Moreover, it was previously reported that $\mathrm{N}$-nitrosamines induce free radicals and therefore oxidized bases [106-110]. In this context, it was demonstrated in vitro that neutrophil activation may generate carcinogenic nitrosamines [65].

\subsubsection{Ammonia}

To our knowledge, there are no reports that deepen in the analysis of DNA damage in enterocytes exposed to high ammonia concentrations. Ammonia caused p53 activation, p21 upregulation, mitochondrial dysfunction, ROS generation, DNA damage and cellular senescence in astrocytes, neurons and hepatic endothelial cells from hepatic encephalopathy patients [111,112]. In epithelial cells from mammary bovine glands, high ammonia concentrations gave rise to the same effects described above [113].

High ammonia concentrations reduce the absorptive capacity and survival rate of the enterocytes. This scenario promotes mucosal turnover, inflammation and fragility of the epithelial intestinal barrier [86].

\subsection{Phytochemicals and Vitamins}

Phytochemicals are micronutrients synthesized by plants and abundant in fruit, vegetables, legumes, tea or wine, highly beneficial to human health [114]. Due to their complexity, $95 \%$ of phytochemicals are absorbed and transformed into more active secondary metabolites by colon microbiota [115]. For instance, soy isoflavones such as daidzein or genistein can be differentially metabolized by microbiota giving alternative secondary metabolites [116,117].

Flavonoids are the largest group of phytochemicals. This group includes isoflavones, anthocyanins and catechins between others.

The anticancer properties of isoflavones and their derivatives have been extensively studied. They are anti-inflammatory and antioxidant molecules that interfere in several cell signaling pathways such as NFKB, AKT or MAPK/ERK, inhibiting cancer growth $[117,118]$.

Anthocyanins are flavonoids with anti-inflammatory, anti-oxidative and anti-cancer properties [119-121]. They modulate bacteria involved in CRC development, by inhibiting the propagation of Helicobacter pylori or promoting the growth of Bifidobacterium spp. and Lactobacillus-Enterococus spp. [122]. Additionally, these compounds are able to modulate the oxidative stress by blocking the phosphorylation of NFKB, which is one of the main causes of DNA damage, and downregulating TNF $\alpha, C O X 2$ and iNOS mRNA expression [123].

Flavonoids commonly named catechins are antioxidants and anti-inflammatory molecules. The underlying mechanisms comprise the inhibition of ROS, hypoxia and NFKB signaling cascades. In addition, catechins modulate $\mathrm{COX} 2$, block of the epidermal growth factor receptor (EGFR) and insulin-like growth factor receptor-1 (IGFR-1) signaling pathways [124].

Green tea catechins modify gut microbiota composition and protect against CRC. An elevated number of bacterial SCFA-producing strains, reduced Fusobacterium spp. and increased FIR/BAC (Firmicutes to Bacteroidetes ratio) ratio were reported [125]. Nevertheless, if catechins concentration is high enough, they behave as pro-oxidant elements generating ROS, DNA damage as well as MMPs production. Furthermore, inhibition of Topoisomerases I and II, which induce DNA damage, have been reported [126,127]. Indeed, 
catechins, in a dose-dependent manner, increase the yield of endoreduplicated cells, a topoisomerase II dysfunction marker [128].

Vitamins are essential organic elements for proper homeostasis. It is widely known that colon microbiota plays an important role in vitamin acquisition. Some bacteria strains can synthesize vitamins of $\mathrm{K}$ and $\mathrm{B}$ groups establishing another vitamin absorption source. Dysbiosis changes microbiota diversity and hence vitamin acquisition by colon may result altered [81].

Low levels of folate (vitamin B9) were associated with different types of cancer (colon, lungs, breast, brain, etc.) in adults, as well as cognitive deficiencies in babies. The underlying mechanism involved is linked to DNA synthesis, repair, and methylation. S-adenosyl methionine (SAM) donates methyl groups to DNA methyltransferases (DNMTs) and complete the DNA methylation process. When folate levels are low, SAM concentration is reduced, leading to DNA hypomethylation that links to proto-oncogenes mRNA expression [129].

Moreover, low folate conditions alter the purine-pyrimidine balance, giving rise to collapsed replication forks and hence one-ended DSBs [130]. Besides, vitamin B9 deficiency inhibits the methylation of dUMP to dTMP, which causes massive uracil incorporation into DNA. BER could result overwhelmed and then high amounts of SSBs and chromosomal breaks are generated [131].

Niacin or vitamin B3 is the precursor of nicotinamide adenine dinucleotide (NAD) and nicotinamide adenine dinucleotide phosphate (NADP). These coenzymes are cofactors in almost all metabolic processes, regulating PARP and sirtuins, among others, which are relevant for genetic and epigenetic regulation [132].

A deficiency in niacin unbalances the $\mathrm{NAD}^{+} / \mathrm{NADH}$ ratio disrupting a large number of processes including DNA repair. Genetic instability and increased risk of cancer development are frequently associated with low levels of niacin, as PARP requires the presence of $\mathrm{NAD}^{+}$to efficiently repair DNA damage [132].

\section{Microbiota Genotoxins}

Dysbiosis conditions and perturbed microbiota may include pathogenic strains that synthesize DNA damaging toxins (Figure 3) [133].

\subsection{Colibactin}

Colibactin is a genotoxic compound produced by some E. coli strains that can induce DSB, chromosomal aberrations and G2/M cell cycle arrest [134].

Three non-ribosomal peptide megasynthases, three polyketide megasynthases, two hybrid megasynthases and some accessory proteins are responsible for Colibactin synthesis as a propeptide [134]. To become active, the propeptide is processed by an inner-membranebound peptidase called Colibactin peptidase $(\mathrm{ClbP})$ that cleaves acyl asparagine residues located in the N-terminus [135].

Active Colibactin can form interstrand cross-links (ICL) with DNA. These structures block replication forks and are processed into one-ended DSB via Fanconi Anemia Repair Pathway (FA) and finally repaired by HR (Figure 1). Indeed, Bossuet-Greif and coworkers found that $\gamma$-H2AX foci (a DSB marker) colocalized with FANCD2 (a FA marker) foci after Colibactin exposure [136]. In agreement with that, Colibactin induced an ATR-mediated replication stress response [136].

NHEJ deficient cells resulted hypersensitive to Colibactin, so apparently, two-ended DSB might be induced [137]. Herzon et al. deciphered more about the nature of Colibactininduced DNA damage. They concluded that Colibactin induces N3-Adenine alkylations that are depurinated by BER into AP sites, promoting a SSB in each DNA strand and finally DSBs are formed $[15,138,139]$. 


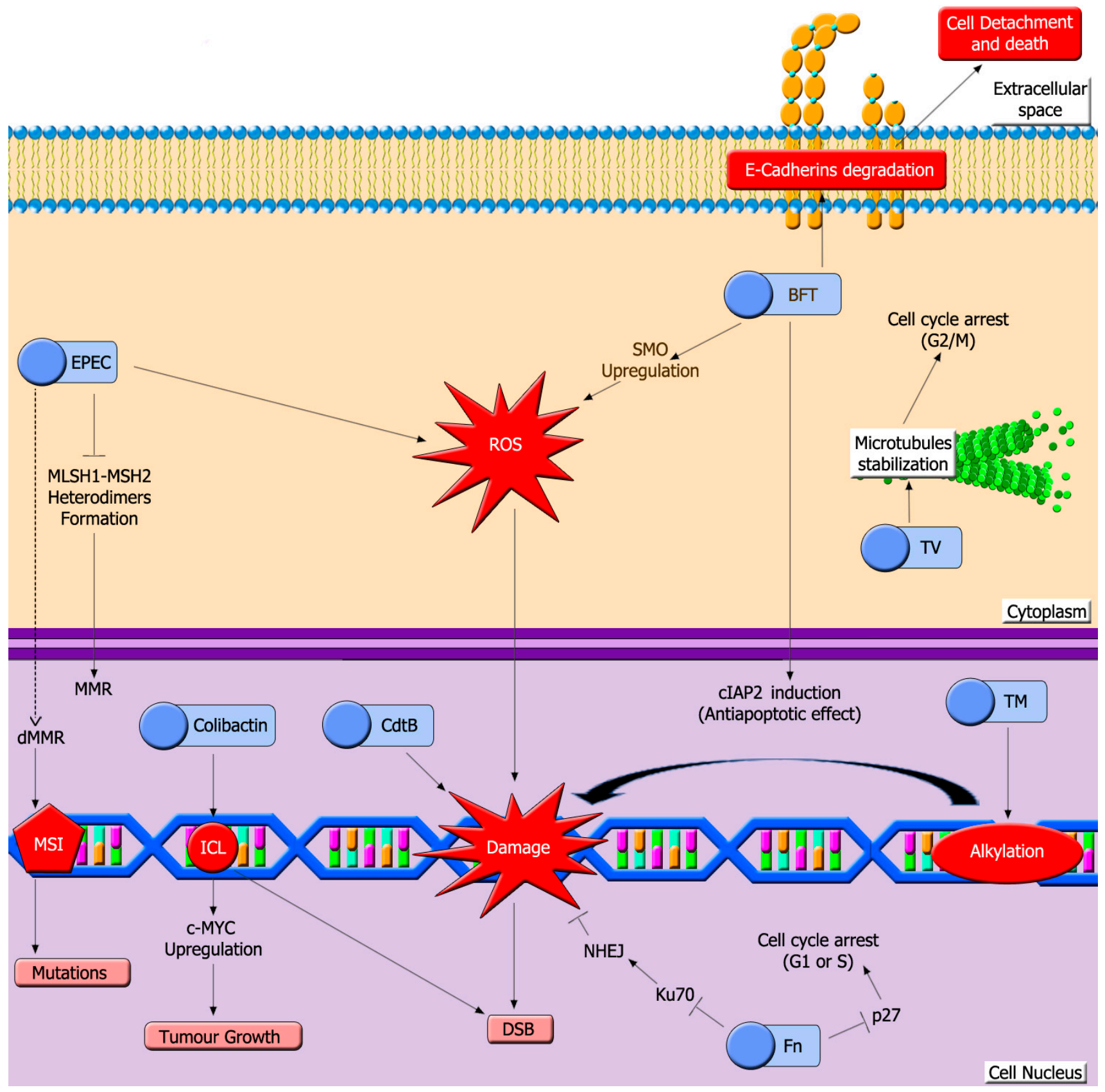

Figure 3. Bacterial toxins induce a high variety of DNA lesions in colon epithelium. A hallmark of colon dysbiosis is the growth of pathogenic bacteria that release toxins that induce DNA damage. Toxins depicted here can damage host DNA through different mechanisms, such as induction of interstrand crosslinks (ICL), generation of ROS, DNA alkylation or inhibiting MMR. EPEC: Enteropathogenic E. coli toxin, CdtB: Cytolethal distending toxin, BFT: Bacteroides fragilis toxin, Fn: Fusobacterium nucleatum toxins, TV: tilivalline, TM: tilimycin, MMR: mismatch repair system, dMMR: defective mismatch repair, MSI: microsatellite instability, DSB: double strand break.

This genotoxin promotes colon tumour growth by inducing a senescent cell phenotype that secretes growth factors. The mechanism is based on an up-regulation of c-MYC protein levels after DNA-damage induction. c-MYC increases microRNA-20a-5p expression that blocks SENP1 mRNA translation [140]. This situation triggers an accumulation of sumoylated-P53. Therefore, the transcriptional activating function and DNA binding capacity of P53 will be abrogated [141]. Most likely sumoylated P53 enhances a senescent cellular state [142]. 


\subsection{Toxins Generated by EPEC}

Enteropathogenic E. coli (EPEC) can settle in the host's gut epithelium through close interaction with intimin adhesion protein and disrupts MMR [143,144].

EPEC effector proteins may cause increased host mutations by depleting the MLH1 and MSH2 protein pool while their transcription is enhanced [145]. The underlying mechanism is mediated by ROS production and could disrupt MLH1 and MSH2 heterodimers formation. This mechanism is not enough to inhibit MMR completely, but Map and EspF proteins can totally block MSH2 $[145,146]$. MMR dysfunction increases spontaneous mutations that can affect tumour suppressor genes. This could explain the axis between chronic EPEC infections and CRC [144,146].

\subsection{Cytolethal Distending Toxins (Cdt)}

$\mathrm{Cdt}$ are a family of cytotoxins produced by different bacterial strains including $\mathrm{He}$ licobacter hepaticus, whose Cdt has a key role in carcinogenesis $[147,148]$. Some of these genotoxins can induce DBSs and G2/M cell cycle arrest [149-151]. The common structure comprises three subunits: a catalytic $\mathrm{CdtB}$ and two lectin-like subunits, which mediate host cell membrane adhesion and invasion [149].

CdtB exhibits PI-3,4,5-triphosphate phosphatase activity and DNase I-like structure and activity. These functions may explain its capacity to induce DSB and cell cycle arrest. Rapamycin alleviates CdtB genotoxicity, so its mechanism of action might be mediated by mTOR $[148,149]$.

These toxins could also affect host gene expression and microbiota composition. Some studies have found an up-regulation of two carcinogenic pathways: peroxisome proliferatoractivated receptors (PPAR) signaling pathway and calcium signaling pathway [148].

\subsection{Bacteroides Fragilis Toxin (BFT)}

BFT is a metalloprotease produced by Enterotoxigenic B. fragilis. The long-term presence of these bacteria, and therefore of BFT, may be related to the pathogenesis of familiar adenomatous polyposis (FAP) contributing to CRC development [152].

BFT is synthesized as a propeptide and processed into its active form before secretion. Once inside target cells, BFT promotes E-cadherins cleavage, stress response activation, cytokine secretion and increased proliferation [153,154].

E-cadherins degradation could be mediated by an unknown BFT surface protein receptor instead of BFT direct action as a metalloprotease [154]. Up-regulation of spermine oxidase (SMO) and the induction of cIAP2 (an antiapoptotic protein) may be some additional mechanisms. SMO is an inflammatory-inducible polyamine catabolic enzyme that promotes the generation of ROS and the induction of DNA damage [153].

\subsection{Fusobacterium Nucleatum (Fn) Toxins}

Fusobacterium nucleatum $(F n)$ is an anaerobic Gram-negative bacteria frequently found in CRC patients' microbiota. There is a correlation between $F n$ infections with genetic and epigenetic changes related to poor CRC prognosis [155].

$F n$ adheres cell surface in order to invade and induce its oncogenic and inflammatory effects. FadA is a protein produced by $F n$ that binds to an 11-amino-acid region of the cell's E-cadherin and promotes $F n$ attachment and invasion [156].

The mechanism underlying $F n$ oncogenic process may be mediated by ROS and pro-inflammatory factors. ROS could be responsible for the hypermethylation of $\mathrm{CPG}$ promoter islands and non-promoter hypomethylation of $\mathrm{CpG}$ regions leading to microsatellite instability and other epigenetic changes. Simultaneously, ROS and pro-inflammatory factors may induce DNA damage [155]. FadA could also contribute to inflammation via the $\beta$-catenin pathway [156].

Furthermore, Fn may disrupt NHEJ repair by downregulating KU70, a protein required to start the NHEJ process, while inducing DSB. Finally, the capacity to downregulate 
P27, a cyclin-dependent kinase inhibitor, increases cell proliferation and causes cell cycle arrest in S phase [157].

\subsection{Klebsiella Oxytoca Enterotoxins}

Antibiotic-associated hemorrhagic colitis (AAHC) is a disease caused by the expansion of colitogenic strains of Klebsiella oxytoca in some patients after antibiotics such as penicillin treatment [158]. Recently biofilms of K. oxytoca were identified in patients with CRC [159].

These bacteria present a gene cluster that encodes a non-ribosomal peptide assembly pathway that produces three secondary metabolites. Two of these metabolites, tilimycin (TM) and tilivalline (TV), present cytotoxic activity. The enzymes encoded by the gene cluster synthesize TV directly while TM requires the reaction between an imine intermediate metabolite of TV with indole [160].

TV is unable to bind to DNA or behave like a genotoxic agent by itself. TV induces microtubule-stabilization targeting tubulin and promoting tubulin-GTP state. This stabilization leads to a G2/M cell cycle arrest that is frequently resolved through multipolar anaphases.

On the other hand, TM binds to and alkylates DNA directly. These lesions trigger a DDR in the host that could lead to the formation of adducts SSBs or DSB after the intervention of repair systems, arresting cells in G1 or S phase. Cells without Cockayne Syndrome group B protein (CSB), Cockayne Syndrome group A protein (CSA) and/or NER XPA resulted hypersensitive to TM, which could be explained by an essential role of TC-NER in the repair of TM induced-DNA lesions [160].

Both toxins may impair the intestinal barrier through two different mechanisms: increasing epithelial apoptosis and decreasing the expression of claudin- 5 and claudin- 8 proteins, contributing to tumour invasion and development [161].

\section{Conclusions}

The relationship between healthy habits, including diet and cancer, has been exhaustively researched. In this review, we envisioned this complex system emphasizing the direct or indirect roles of microbiota in DNA damage induction.

The diet and microbiota axis seems to be an indivisible factor. Microbiome's metabolites may act as pro or anti-carcinogenic compounds depending on diet that in turn acts by remodeling microbiota composition itself. In this context, normal microbiota protects the epithelium barrier against harmful bacteria, inflammation, and DNA damage while diet-induced dysbiosis may lead to the opposite effects.

In conclusion, a greater understanding of DNA damage pathways induced by a dietmodified microbiota may lead to new approaches and treatments to decrease the risk of CRC development.

Author Contributions: The manuscript was designed, written and reviewed by B.B. and M.L.O. A.R.-D., N.P., L.M.-L. and J.C.-P. consulted literature and wrote some parts of the document. B.B., M.L.O. and A.R.-D. have designed figures. A.R.-D. finally drew all figures. All authors have read and agreed to the published version of the manuscript.

Funding: This research was funded by Plan Andaluz de Investigación, Desarrollo e Innovación (PAIDI) 2020, grant number P18-RT-3324. The APC was funded by P18-RT-3324.

Conflicts of Interest: The authors declare no conflict of interest.

\section{References}

1. Dominguez-Bello, M.G.; Godoy-Vitorino, F.; Knight, R.; Blaser, M.J. Role of the microbiome in human development. Gut 2019, 68, 1108-1114. [CrossRef]

2. Bianconi, E.; Piovesan, A.; Facchin, F.; Beraudi, A.; Casadei, R.; Frabetti, F.; Vitale, L.; Pelleri, M.C.; Tassani, S.; Piva, F.; et al. An estimation of the number of cells in the human body. Ann. Hum. Biol. 2013, 40, 463-471. [CrossRef]

3. Sender, R.; Fuchs, S.; Milo, R. Are We Really Vastly Outnumbered? Revisiting the Ratio of Bacterial to Host Cells in Humans. Cell 2016, 164, 337-340. [CrossRef]

4. Skolnick, S.D.; Greig, N.H. Microbes and Monoamines: Potential Neuropsychiatric Consequences of Dysbiosis. Trends Neurosci. 2019, 42, 151-163. [CrossRef] [PubMed] 
5. Abdellatif, A.M.; Sarvetnick, N.E. Current understanding of the role of gut dysbiosis in type 1 diabetes. J. Diabetes 2019, 11, 632-644. [CrossRef] [PubMed]

6. Bhatt, A.P.; Redinbo, M.R.; Bultman, S.J. The role of the microbiome in cancer development and therapy. CA Cancer J. Clin. 2017, 67, 326-344. [CrossRef]

7. Thomas, R.M.; Jobin, C. The Microbiome and Cancer: Is the "Oncobiome" Mirage Real? Trends Cancer 2015, 1, 24-35. [CrossRef]

8. Nelson, M.H.; Diven, M.A.; Huff, L.W.; Paulos, C.M. Harnessing the Microbiome to Enhance Cancer Immunotherapy. J. Immunol. Res. 2015, 2015. [CrossRef]

9. Gopalakrishnan, V.; Helmink, B.A.; Spencer, C.N.; Reuben, A.; Wargo, J.A. The Influence of the Gut Microbiome on Cancer, Immunity, and Cancer Immunotherapy. Cancer Cell 2018, 33, 570-580. [CrossRef] [PubMed]

10. Carmi, Y.; Dotan, S.; Rider, P.; Kaplanov, I.; White, M.R.; Baron, R.; Abutbul, S.; Huszar, M.; Dinarello, C.A.; Apte, R.N.; et al. The Role of IL-1 $\beta$ in the Early Tumour Cell-Induced Angiogenic Response. J. Immunol. 2013, 190, 3500-3509. [CrossRef]

11. Kipanyula, M.J.; Seke Etet, P.F.; Vecchio, L.; Farahna, M.; Nukenine, E.N.; Nwabo Kamdje, A.H. Signaling pathways bridging microbial-triggered inflammation and cancer. Cell. Signal. 2013, 25, 403-416. [CrossRef]

12. Ono, M. Molecular links between tumour angiogenesis and inflammation: Inflammatory stimuli of macrophages and cancer cells as targets for therapeutic strategy. Cancer Sci. 2008, 99, 1501-1506. [CrossRef]

13. Helleday, T. DNA repair as treatment target. Eur. J. Cancer 2011, 47, S333-S335. [CrossRef]

14. Puigvert, J.C.; Sanjiv, K.; Helleday, T. Targeting DNA repair, DNA metabolism and replication stress as anti-cancer strategies. FEBS J. 2016, 283, 232-245. [CrossRef]

15. Helleday, T.; Petermann, E.; Lundin, C.; Hodgson, B.; Sharma, R.A. DNA repair pathways as targets for cancer therapy. Nat. Rev. Cancer 2008, 8, 193-204. [CrossRef] [PubMed]

16. Caldecott, K.W. Mammalian DNA base excision repair: Dancing in the moonlight. DNA Repair 2020, 93, 102921. [CrossRef] [PubMed]

17. Orta, M.L.; Höglund, A.; Calderón-Montaño, J.M.; Domínguez, I.; Burgos-Morón, E.; Visnes, T.; Pastor, N.; Ström, C.; López-lázaro, M.; Helleday, T. The PARP inhibitor Olaparib disrupts base excision repair of 5-aza-2'-deoxycytidine lesions. Nucleic Acids Res. 2014, 42, 9108-9120. [CrossRef]

18. Iyer, R.R.; Pluciennik, A.; Burdett, V.; Modrich, P.L. DNA Mismatch Repair: Functions and Mechanisms. Chem. Rev. 2006. [CrossRef] [PubMed]

19. Modrich, P. Mechanisms in eukaryotic mismatch repair. J. Biol. Chem. 2006, 281, 30305-30309. [CrossRef]

20. Reilly, N.M.; Novara, L.; Di Nicolantonio, F.; Bardelli, A. Exploiting DNA repair defects in colorectal cancer. Mol. Oncol. 2019, 13, 681-700. [CrossRef]

21. Gelsomino, F.; Barbolini, M.; Spallanzani, A.; Pugliese, G.; Cascinu, S. The evolving role of microsatellite instability in colorectal cancer: A review. Cancer Treat. Rev. 2016, 51, 19-26. [CrossRef]

22. Guillotin, D.; Martin, S.A. Exploiting DNA mismatch repair deficiency as a therapeutic strategy. Exp. Cell Res. 2014, 329, 110-115. [CrossRef]

23. Ruiz-Bañobre, J.; Goel, A. DNA Mismatch Repair Deficiency and Immune Checkpoint Inhibitors in Gastrointestinal Cancers. Gastroenterology 2019, 156, 890-903. [CrossRef]

24. Hoeijmakers, J.H.J. Genome maintenance mechanisms for preventing cancer. Nature 2001, 411, 366-374. [CrossRef] [PubMed]

25. Vítor, A.C.; Huertas, P.; Legube, G.; de Almeida, S.F. Studying DNA Double-Strand Break Repair: An Ever-Growing Toolbox. Front. Mol. Biosci. 2020, 7, 24. [CrossRef] [PubMed]

26. Shackelford, R.; Ozluk, E.; Islam, M.Z.; Hopper, B.; Meram, A.; Ghali, G.; Kevil, C.G. Hydrogen sulfide and DNA repair. Redox Biol. 2021, 38, 101675. [CrossRef]

27. Bradbury, A.; Hall, S.; Curtin, N.; Drew, Y. Targeting ATR as Cancer Therapy: A new era for synthetic lethality and synergistic combinations? Pharmacol. Ther. 2020, 207, 107450. [CrossRef]

28. Chen, J.; Shen, X.; Pardue, S.; Meram, A.T.; Rajendran, S.; Ghali, G.E.; Kevil, C.G.; Shackelford, R.E. The Ataxia telangiectasiamutated and Rad3-related protein kinase regulates cellular hydrogen sulfide concentrations. DNA Repair 2019, 73, 55-63. [CrossRef]

29. Yue, X.; Bai, C.; Xie, D.; Ma, T.; Zhou, P.K. DNA-PKcs: A Multi-Faceted Player in DNA Damage Response. Front. Genet. 2020, 11. [CrossRef] [PubMed]

30. Helleday, T. Pathways for mitotic homologous recombination in mammalian cells. Mutat. Res. Fundam. Mol. Mech. Mutagen. 2003, 532, 103-115. [CrossRef] [PubMed]

31. Zhao, F.; Kim, W.; Kloeber, J.A.; Lou, Z. DNA end resection and its role in DNA replication and DSB repair choice in mammalian cells. Exp. Mol. Med. 2020, 52, 1705-1714. [CrossRef] [PubMed]

32. Sung, H.; Ferlay, J.; Siegel, R.L.; Laversanne, M.; Soerjomataram, I.; Jemal, A.; Bray, F. Global Cancer Statistics 2020: GLOBOCAN Estimates of Incidence and Mortality Worldwide for 36 Cancers in 185 Countries. CA Cancer J. Clin. 2021, 71, 209-249. [CrossRef] [PubMed]

33. Müller, M.F.; Ibrahim, A.E.K.; Arends, M.J. Molecular pathological classification of colorectal cancer. Virchows Arch. 2016, 469, 125-134. [CrossRef] [PubMed] 
34. Whiffin, N.; Hosking, F.J.; Farrington, S.M.; Palles, C.; Dobbins, S.E.; Zgaga, L.; Lloyd, A.; Kinnersley, B.; Gorman, M.; Tenesa, A.; et al. Identification of susceptibility loci for colorectal cancer in a genome-wide meta-analysis. Hum. Mol. Genet. 2014, 23, 4729-4737. [CrossRef] [PubMed]

35. Kantor, M.; Sobrado, J.; Patel, S.; Eiseler, S.; Ochner, C. Hereditary Colorectal Tumours: A Literature Review on MUTYHAssociated Polyposis. Gastroenterol. Res. Pract. 2017, 2017. [CrossRef]

36. Puccini, A.; Berger, M.D.; Naseem, M.; Tokunaga, R.; Battaglin, F.; Cao, S.; Hanna, D.L.; McSkane, M.; Soni, S.; Zhang, W.; et al. Colorectal cancer: Epigenetic alterations and their clinical implications. Biochim. Biophys. Acta - Rev. Cancer 2017, 1868, 439-448. [CrossRef]

37. Hale, V.L.; Jeraldo, P.; Chen, J.; Mundy, M.; Yao, J.; Priya, S.; Keeney, G.; Lyke, K.; Ridlon, J.; White, B.A.; et al. Distinct microbes, metabolites, and ecologies define the microbiome in deficient and proficient mismatch repair colorectal cancers. Genome Med. 2018, 10, 78. [CrossRef]

38. Mármol, I.; Sánchez-de-Diego, C.; Dieste, A.P.; Cerrada, E.; Yoldi, M.J.R. Colorectal carcinoma: A general overview and future perspectives in colorectal cancer. Int. J. Mol. Sci. 2017, 18, 197. [CrossRef]

39. Fearon, E.R.; Vogelstein, B. A genetic model for colorectal tumourigenesis. Cell 1990, 61, 759-767. [CrossRef]

40. O'Keefe, S.J.D. Diet, microorganisms and their metabolites, and colon cancer. Nat. Rev. Gastroenterol. Hepatol. 2016, 13, 691-706. [CrossRef] [PubMed]

41. Louis, P.; Hold, G.L.; Flint, H.J. The gut microbiota, bacterial metabolites and colorectal cancer. Nat. Rev. Microbiol. 2014, 12, 661-672. [CrossRef] [PubMed]

42. Wan, G.; Xie, M.; Yu, H.; Chen, H. Intestinal dysbacteriosis activates tumour-associated macrophages to promote epithelialmesenchymal transition of colorectal cancer. Innate Immun. 2018, 24, 480-489. [CrossRef]

43. Irwin, C.R.; Myrillas, T.T.; Traynor, P.; Leadbetter, N.; Cawston, T.E. The Role of Soluble Interleukin (IL)-6 Receptor in Mediating the effects of IL- 6 on Matrix Metalloproteinase-1 and Tissue Inhibitor of Metalloproteinase-1 Expression by Gingival Fibroblasts. J. Periodontol. 2002, 73, 741-747. [CrossRef] [PubMed]

44. Nakahara, H.; Song, J.; Sugimoto, M.; Hagihara, K.; Kishimoto, T.; Yoshizaki, K.; Nishimoto, N. Anti-interleukin-6 receptor antibody therapy reduces vascular endothelial growth factor production in rheumatoid arthritis. Arthritis Rheum. 2003, 48, 1521-1529. [CrossRef]

45. Cai, Q.; Huang, H.; Bai, B.; Lin, S.; Gao, Y.; Xia, Y.; Wang, X.; Lu, J. IL-6 Promotes Cell Proliferation and Antiapoptosis through Activation of the JAK/STAT3 Pathway in Patients with NK/T-Cell Lymphoma and Correlates with Poor Treatmemt Outcome. Blood 2013, 122, 1758. [CrossRef]

46. McDermott, E.P.; O'Neill, L.A.J. Ras participates in the activation of p38 MAPK by interleukin-1 by associating with IRAK, IRAK2, TRAF6, and TAK-1. J. Biol. Chem. 2002, 277, 7808-7815. [CrossRef]

47. Palsson, E.M.; Popoff, M.; Thelestam, M.; O’Neill, L.A.J. Divergent roles for Ras and Rap in the activation of p38 mitogenactivated protein kinase by interleukin-1. J. Biol. Chem. 2000, 275, 7818-7825. [CrossRef]

48. Voronov, E.; Shouval, D.S.; Krelin, Y.; Cagnano, E.; Benharroch, D.; Iwakura, Y.; Dinarello, C.A.; Apte, R.N. IL-1 is required for tumour invasiveness and angiogenesis. Proc. Natl. Acad. Sci. USA 2003, 100, 2645-2650. [CrossRef] [PubMed]

49. Chen, W.; Liu, F.; Ling, Z.; Tong, X.; Xiang, C. Human Intestinal Lumen and Mucosa-Associated Microbiota in Patients with Colorectal Cancer. PLoS ONE 2012, 7, e39743. [CrossRef] [PubMed]

50. Wang, F.M.; Liu, H.Q.; Liu, S.R.; Tang, S.P.; Yang, L.; Feng, G.S. SHP-2 promoting migration and metastasis of MCF-7 with loss of E-cadherin, dephosphorylation of FAK and secretion of MMP-9 induced by IL-1 $\beta$ in vivo and in vitro. Breast Cancer Res. Treat. 2005, 89, 5-14. [CrossRef]

51. Pannone, G.; Santoro, A.; Feola, A.; Bufo, P.; Papagerakis, P.; Muzio, L.; Staibano, S.; Ionna, F.; Longo, F.; Franco, R.; et al. The Role of E-Cadherin Down-Regulation in Oral Cancer: CDH1 Gene Expression and Epigenetic Blockage. Curr. Cancer Drug Targets 2014, 14, 115-127. [CrossRef] [PubMed]

52. Wong, S.H.M.; Fang, C.M.; Chuah, L.H.; Leong, C.O.; Ngai, S.C. E-cadherin: Its dysregulation in carcinogenesis and clinical implications. Crit. Rev. Oncol. Hematol. 2018, 121, 11-22. [CrossRef]

53. Lingappan, K. NF-kB in oxidative stress. Curr. Opin. Toxicol. 2018, 7, 81-86. [CrossRef]

54. Lin, S.; Li, Y.; Zamyatnin, A.A.; Werner, J.; Bazhin, A.V. Reactive oxygen species and colorectal cancer. J. Cell. Physiol. 2018, 233, 5119-5132. [CrossRef]

55. Storz, P. Reactive oxygen species in tumour progression. Front. Biosci. 2005, 10, 1881-1896. [CrossRef] [PubMed]

56. Liou, G.Y.; Storz, P. Reactive oxygen species in cancer. Free Radic. Res. 2010, 44, 479-496. [CrossRef]

57. Nikitaki, Z.; Hellweg, C.E.; Georgakilas, A.G.; Ravanat, J.L. Stress-induced DNA damage biomarkers: Applications and limitations. Front. Chem. 2015, 3, 35. [CrossRef] [PubMed]

58. Irrazabal, T.; Thakur, B.K.; Kang, M.; Malaise, Y.; Streutker, C.; Wong, E.O.Y.; Copeland, J.; Gryfe, R.; Guttman, D.S.; Navarre, W.W.; et al. Limiting oxidative DNA damage reduces microbe-induced colitis-associated colorectal cancer. Nat. Commun. 2020, 11. [CrossRef]

59. Ohshima, H.; Bartsch, H. Chronic infections and inflammatory processes as cancer risk factors: Possible role of nitric oxide in carcinogenesis. Mutat. Res. Fundam. Mol. Mech. Mutagen. 1994, 305, 253-264. [CrossRef]

60. Lancaster, J.R.; Xie, K. Tumours face NO problems? Cancer Res. 2006, 66, 6459-6462. [CrossRef] 
61. Gaston, B.; Drazen, J.M.; Loscalzo, J.; Stamler, J.S. The biology of nitrogen oxides in the airways. Am. J. Respir. Crit. Care Med. 1994, 149, 538-551. [CrossRef]

62. Edwards, R.A.; Witherspoon, M.; Wang, K.; Afrasiabi, K.; Pham, T.; Birnbaumer, L.; Lipkin, S.M. Epigenetic repression of DNA mismatch repair by inflammation and hypoxia in inflammatory bowel disease-associated colorectal cancer. Cancer Res. 2009, 69, 6423-6429. [CrossRef]

63. Sárközy, M.; Kovács, Z.Z.A.; Kovács, M.G.; Gáspár, R.; Szúcs, G.; Dux, L. Mechanisms and Modulation of Oxidative/Nitrative Stress in Type 4 Cardio-Renal Syndrome and Renal Sarcopenia. Front. Physiol. 2018, 9, 1648. [CrossRef]

64. Vermeer, I.T.M.; Van Maanen, J.M.S. Nitrate exposure and the endogenous formation of carcinogenic nitrosamines in humans. Rev. Environ. Health 2001, 16, 105-116. [CrossRef] [PubMed]

65. Vermeer, I.T.M.; Henderson, L.Y.; Moonen, E.J.C.; Engels, L.G.J.B.; Dallinga, J.W.; Van Maanen, J.M.S.; Kleinjans, C.S. Neutrophilmediated formation of carcinogenic $\mathrm{N}$-nitroso compounds in an in vitro model for intestinal inflammation. Toxicol. Lett. 2004, 154, 175-182. [CrossRef] [PubMed]

66. Zenser, T.V.; Lakshmi, V.M.; Schut, H.A.J.; Zhou, H.j.; Josephy, P.D. Activation of aminoimidazole carcinogens by nitrosation: Mutagenicity and nucleotide adducts. Mutat. Res. Genet. Toxicol. Environ. Mutagen. 2009, 673, 109-115. [CrossRef]

67. Alhinai, E.A.; Walton, G.E.; Commane, D.M. The role of the gut microbiota in colorectal cancer causation. Int. J. Mol. Sci. 2019, 20, 5295. [CrossRef] [PubMed]

68. Arnold, M.; Sierra, M.S.; Laversanne, M.; Soerjomataram, I.; Jemal, A.; Bray, F. Global patterns and trends in colorectal cancer incidence and mortality. Gut 2017, 66, 683-691. [CrossRef]

69. Abu-Ghazaleh, N.; Chua, W.J.; Gopalan, V. Intestinal microbiota and its association with colon cancer and red/processed meat consumption. J. Gastroenterol. Hepatol. 2021, 36, 75-88. [CrossRef] [PubMed]

70. O'Keefe, S.J.D.; Li, J.V.; Lahti, L.; Ou, J.; Carbonero, F.; Mohammed, K.; Posma, J.M.; Kinross, J.; Wahl, E.; Ruder, E.; et al. Fat, fibre and cancer risk in African Americans and rural Africans. Nat. Commun. 2015, 6. [CrossRef] [PubMed]

71. Soldati, L.; Di Renzo, L.; Jirillo, E.; Ascierto, P.A.; Marincola, F.M.; De Lorenzo, A. The influence of diet on anti-cancer immune responsiveness. J. Transl. Med. 2018, 16, 75. [CrossRef] [PubMed]

72. Bultman, S.J. Interplay between diet, gut microbiota, epigenetic events, and colorectal cancer. Mol. Nutr. Food Res. 2017, 61, 1500902. [CrossRef]

73. Sun, X.; Zhu, M.J. Butyrate Inhibits Indices of Colorectal Carcinogenesis via Enhancing $\alpha$-Ketoglutarate-Dependent DNA Demethylation of Mismatch Repair Genes. Mol. Nutr. Food Res. 2018, 62, 1700932. [CrossRef]

74. Lucas, C.; Barnich, N.; Nguyen, H.T.T. Microbiota, Inflammation and Colorectal Cancer. Int. J. Mol. Sci. 2017, 18, 1310. [CrossRef]

75. Abdulla Al Hinai, E.; Kullamethee, P.; Rowland, I.R.; Swann, J.; Walton, G.E.; Commane, D.M. Gut Microbes Modelling the role of microbial p-cresol in colorectal genotoxicity Modelling the role of microbial p-cresol in colorectal genotoxicity. Gut Microbes 2018. [CrossRef]

76. Kasai, C.; Sugimoto, K.; Moritani, I.; Tanaka, J.; Oya, Y.; Inoue, H.; Tameda, M.; Shiraki, K.; Ito, M.; Takei, Y.; et al. Comparison of human gut microbiota in control subjects and patients with colorectal carcinoma in adenoma: Terminal restriction fragment length polymorphism and next-generation sequencing analyses. Oncol. Rep. 2016, 35, 325-333. [CrossRef] [PubMed]

77. Morrison, D.J.; Preston, T. Formation of short chain fatty acids by the gut microbiota and their impact on human metabolism. Gut Microbes 2016, 7, 189-200. [CrossRef]

78. Jahani-Sherafat, S.; Alebouyeh, M.; Moghim, S.; Amoli, H.A.; Ghasemian-Safaei, H. Role of gut microbiota in the pathogenesis of colorectal cancer; A review article. Gastroenterol. Hepatol. Bed Bench 2018, 11, 101-109. [PubMed]

79. Donohoe, D.R.; Collins, L.B.; Wali, A.; Bigler, R.; Sun, W.; Bultman, S.J. The Warburg Effect Dictates the Mechanism of ButyrateMediated Histone Acetylation and Cell Proliferation. Mol. Cell 2012, 48, 612-626. [CrossRef]

80. Salek Farrokhi, A.; Mohammadlou, M.; Abdollahi, M.; Eslami, M.; Yousefi, B. Histone Deacetylase Modifications by Probiotics in Colorectal Cancer. J. Gastrointest. Cancer 2020, 51, 754-764. [CrossRef]

81. Rowland, I.; Gibson, G.; Heinken, A.; Scott, K.; Swann, J.; Thiele, I.; Tuohy, K. Gut microbiota functions: Metabolism of nutrients and other food components. Eur. J. Nutr. 2018, 57, 1-24. [CrossRef]

82. Payne, C. Hydrophobic bile acids, genomic instability, Darwinian selection, and colon carcinogenesis. Clin. Exp. Gastroenterol. 2008, 1, 19. [CrossRef]

83. Farhana, L.; Nangia-Makker, P.; Arbit, E.; Shango, K.; Sarkar, S.; Mahmud, H.; Hadden, T.; Yu, Y.; Majumdar, A.P.N. Bile acid: A potential inducer of colon cancer stem cells. Stem Cell Res. Ther. 2016, 7, 181. [CrossRef] [PubMed]

84. Ridlon, J.M.; Wolf, P.G.; Gaskins, H.R. Taurocholic acid metabolism by gut microbes and colon cancer. Gut Microbes 2016, 7, 201-215. [CrossRef] [PubMed]

85. Rosignoli, P.; Fabiani, R.; De Bartolomeo, A.; Fuccelli, R.; Pelli, M.A.; Morozzi, G. Genotoxic effect of bile acids on human normal and tumour colon cells and protection by dietary antioxidants and butyrate. Eur. J. Nutr. 2008, 47, 301-309. [CrossRef] [PubMed]

86. Yao, C.K.; Muir, J.G.; Gibson, P.R. Review article: Insights into colonic protein fermentation, its modulation and potential health implications. Aliment. Pharmacol. Ther. 2016, 43, 181-196. [CrossRef] [PubMed]

87. Andriamihaja, M.; Lan, A.; Beaumont, M.; Audebert, M.; Wong, X.; Yamada, K.; Yin, Y.; Tomé, D.; Carrasco-Pozo, C.; Gotteland, M.; et al. The deleterious metabolic and genotoxic effects of the bacterial metabolite p-cresol on colonic epithelial cells. Free Radic. Biol. Med. 2015, 85, 219-227. [CrossRef] [PubMed] 
88. Lecerf, J.M.; Dépeint, F.; Clerc, E.; Dugenet, Y.; Niamba, C.N.; Rhazi, L.; Cayzeele, A.; Abdelnour, G.; Jaruga, A.; Younes, H.; et al. Xylo-oligosaccharide (XOS) in combination with inulin modulates both the intestinal environment and immune status in healthy subjects, while XOS alone only shows prebiotic properties. Br. J. Nutr. 2012, 108, 1847-1858. [CrossRef] [PubMed]

89. Boutwell, R.K.; Bosch, D.K. The tumour-promoting action of phenol and related compounds for mouse skin. Cancer Res. 1959, 19, 413-424.

90. Attene-Ramos, M.S.; Nava, G.M.; Muellner, M.G.; Wagner, E.D.; Plewa, M.J.; Gaskins, H.R. DNA damage and toxicogenomic analyses of hydrogen sulfide in human intestinal epithelial FHs 74 Int cells. Environ. Mol. Mutagen. 2010, 51, 304-314. [CrossRef]

91. Aroca, A.; Gotor, C.; Bassham, D.C.; Romero, L.C. Hydrogen Sulfide: From a Toxic Molecule to a Key Molecule of Cell Life. Antioxidants 2020, 9, 621. [CrossRef]

92. Wu, D.; Si, W.; Wang, M.; Lv, S.; Ji, A.; Li, Y. Hydrogen sulfide in cancer: Friend or foe? Nitric Oxide - Biol. Chem. 2015, 50, 38-45. [CrossRef] [PubMed]

93. Cai, W.; Wang, M.; Ju, L.; Wang, C.; Zhu, Y. Hydrogen sulfide induces human colon cancer cell proliferation: Role of Akt, ERK and p21. Cell Biol. Int. 2010, 34, 565-572. [CrossRef]

94. Wu, Y.C.; Wang, X.J.; Yu, L.; Chan, F.K.L.; Cheng, A.S.L.; Yu, J.; Sung, J.J.Y.; Wu, W.K.K.; Cho, C.H. Hydrogen sulfide lowers proliferation and induces protective autophagy in colon epithelial cells. PLoS ONE 2012, 7. [CrossRef] [PubMed]

95. Levy, J.M.M.; Towers, C.G.; Thorburn, A. Targeting autophagy in cancer. Nat. Rev. Cancer 2017, 17, 528-542. [CrossRef] [PubMed]

96. Wu, D.; Wang, H.; Teng, T.; Duan, S.; Ji, A.; Li, Y. Hydrogen sulfide and autophagy: A double edged sword. Pharmacol. Res. 2018, 131, 120-127. [CrossRef]

97. Attene-Ramos, M.S.; Wagner, E.D.; Plewa, M.J.; Gaskins, H.R. Evidence that hydrogen sulfide is a genotoxic agent. Mol. Cancer Res. 2006, 4, 9-14. [CrossRef]

98. Attene-Ramos, M.S.; Wagner, E.D.; Gaskins, H.R.; Plewa, M.J. Hydrogen sulfide induces direct radical-associated DNA damage. Mol. Cancer Res. 2007, 5, 455-459. [CrossRef]

99. Güerci, A.; Liviac, D.; Marcos, R. Detection of excision repaired DNA damage in the comet assay by using Ara-C and hydroxyurea in three different cell types. Cell Biol. Toxicol. 2009, 25, 73-80. [CrossRef]

100. Deplancke, B.; Gaskins, H.R. Hydrogen sulfide induces serum-independent cell cycle entry in nontransformed rat intestinal epithelial cells. FASEB J. 2003, 17, 1310-1312. [CrossRef] [PubMed]

101. Evans, C.L. The toxicity of hydrogen sulphide and other sulphides. Q. J. Exp. Physiol. Cogn. Med. Sci. 1967, 52, 231-248. [CrossRef]

102. Shattuck-Brandt, R.L.; Varilek, G.W.; Radhika, A.; Yang, F.; Washington, M.K.; DuBois, R.N. Cyclooxygenase 2 expression is increased in the stroma of colon carcinomas from IL-10(-/-) mice. Gastroenterology 2000, 118, 337-345. [CrossRef]

103. Eberhart, C.E.; Coffey, R.J.; Radhika, A.; Giardiello, F.M.; Ferrenbach, S.; Dubois, R.N. Up-regulation of cyclooxygenase 2 gene expression in human colorectal adenomas and adenocarcinomas. Gastroenterology 1994, 107, 1183-1188. [CrossRef]

104. Zhi, L.; Ang, A.D.; Zhang, H.; Moore, P.K.; Bhatia, M. Hydrogen sulfide induces the synthesis of proinflammatory cytokines in human monocyte cell line U937 via the ERK-NF-kB pathway. J. Leukoc. Biol. 2007, 81, 1322-1332. [CrossRef] [PubMed]

105. Jarrett, S.G.; Horrell, E.M.W.; Christian, P.A.; Vanover, J.C.; Boulanger, M.C.; Zou, Y.; D'Orazio, J.A. PKA-Mediated Phosphorylation of ATR Promotes Recruitment of XPA to UV-Induced DNA Damage. Mol. Cell 2014, 54, 999-1011. [CrossRef]

106. Delgado, M.E.; Haza, A.I.; Arranz, N.; García, A.; Morales, P.; Delgado, M.E.; Haza, A.A.I.; Arranz, A.N.; García, A.; Morales, A.P. Dietary polyphenols protect against N-nitrosamines and benzo(a)pyrene-induced DNA damage (strand breaks and oxidized purines/pyrimidines) in HepG2 human hepatoma cells. Eur. J. Nutr. 2008, 47, 479-490. [CrossRef] [PubMed]

107. Guttenplan, J.B. N-Nitrosamines: Bacterial mutagenesis and in vitro metabolism. Mutat. Res. 1987, 186, 81-134. [CrossRef]

108. Zink, C.N.; Soissons, N.; Fishbein, J.C. Products of the direct reaction of the diazonium ion of a metabolite of the carcinogen N -nitrosomorpholine with purines of nucleosides and dna. Chem. Res. Toxicol. 2010, 23, 1223-1233. [CrossRef]

109. Arranz, N.; Haza, A.I.; García, A.; Rafter, J.; Morales, P. Protective effect of vitamin C towards N-nitrosamine-induced DNA damage in the single-cell gel electrophoresis (SCGE)/HepG2 assay. Toxicol. Vitr. 2007, 21, 1311-1317. [CrossRef]

110. Arranz, N.; Haza, A.I.; García, A.; Möller, L.; Rafter, J.; Morales, P. Protective effects of organosulfur compounds towards N-nitrosamine-induced DNA damage in the single-cell gel electrophoresis (SCGE)/HepG2 assay. Food Chem. Toxicol. 2007, 45, 1662-1669. [CrossRef]

111. Bobermin, L.D.; Souza, D.O.; Gonçalves, C.A.; Quincozes-Santos, A. Resveratrol prevents ammonia-induced mitochondrial dysfunction and cellular redox imbalance in C6 astroglial cells. Nutr. Neurosci. 2018, 21, 276-285. [CrossRef]

112. Görg, B.; Karababa, A.; Häussinger, D. Hepatic Encephalopathy and Astrocyte Senescence. J. Clin. Exp. Hepatol. 2018, 8, 294-300. [CrossRef] [PubMed]

113. Wang, F.; Chen, S.; Jiang, Y.; Zhao, Y.; Sun, L.; Zheng, B.; Chen, L.; Liu, Z.; Zheng, X.; Yi, K.; et al. Effects of ammonia on apoptosis and oxidative stress in bovine mammary epithelial cells. Mutagenesis 2018, 33. [CrossRef]

114. Wilson, A.S.; Koller, K.R.; Ramaboli, M.C.; Nesengani, L.T.; Ocvirk, S.; Chen, C.; Flanagan, C.A.; Sapp, F.R.; Merritt, Z.T.; Bhatti, F.; et al. Diet and the Human Gut Microbiome: An International Review. Dig. Dis. Sci. 2020, 65, 723-740. [CrossRef] [PubMed]

115. Espín, J.C.; González-Sarrías, A.; Tomás-Barberán, F.A. The gut microbiota: A key factor in the therapeutic effects of (poly)phenols. Biochem. Pharmacol. 2017, 139, 82-93. [CrossRef] [PubMed]

116. Yang, Z.P.; Zhao, Y.; Huang, F.; Chen, J.; Yao, Y.H.; Li, J.; Wu, X.N. Equol inhibits proliferation of human gastric carcinoma cells via modulating Akt pathway. World J. Gastroenterol. 2015, 21, 10385-10399. [CrossRef] 
117. Herman, C.; Adlercreãoetz, T.; Goldin, B.R.; Gorbach, S.L.; Hã-Ckerstedt, K.A.V.; Watanabe, S.; Hämäläinen, E.K.; Helene Markkanen, M.; Mäkelä, T.H.; Wähälä, K.T.; et al. Soybean Phytoestrogen Intake and Cancer Risk12. J. Nutr. 1995, 125, 757S-770S.

118. Arora, A.; Nair, M.G.; Strasburg, G.M. Antioxidant activities of isoflavones and their biological metabolites in a liposomal system. Arch. Biochem. Biophys. 1998, 356, 133-141. [CrossRef]

119. Casto, B.C.; Knobloch, T.J.; Galioto, R.L.; Yu, Z.; Accurso, B.T.; Warner, B.M. Chemoprevention of oral cancer by lyophilized strawberries. Anticancer Res. 2013, 33, 4757-4766.

120. Balansky, R.; Ganchev, G.; Iltcheva, M.; Kratchanova, M.; Denev, P.; Kratchanov, C.; Polasa, K.; D'Agostini, F.; Steele, V.E.; De Flora, S. Inhibition of lung tumour development by berry extracts in mice exposed to cigarette smoke. Int. J. Cancer 2012, 131, 1991-1997. [CrossRef]

121. Somasagara, R.R.; Hegde, M.; Chiruvella, K.K.; Musini, A.; Choudhary, B.; Raghavan, S.C. Extracts of Strawberry Fruits Induce Intrinsic Pathway of Apoptosis in Breast Cancer Cells and Inhibits Tumour Progression in Mice. PLoS ONE 2012, 7, e47021. [CrossRef] [PubMed]

122. Duda-Chodak, A.; Tarko, T.; Satora, P.; Sroka, P. Interaction of dietary compounds, especially polyphenols, with the intestinal microbiota: A review. Eur. J. Nutr. 2015, 54, 325-341. [CrossRef]

123. Shi, N.; Clinton, S.K.; Liu, Z.; Wang, Y.; Riedl, K.M.; Schwartz, S.J.; Zhang, X.; Pan, Z.; Chen, T. Strawberry phytochemicals inhibit azoxymethane/dextran sodium sulfate-induced colorectal carcinogenesis in Crj: CD-1 mice. Nutrients 2015, 7, 1696-1715. [CrossRef] [PubMed]

124. Carrera-Quintanar, L.; Roa, R.I.L.; Quintero-Fabián, S.; Sánchez-Sánchez, M.A.; Vizmanos, B.; Ortuño-Sahagún, D. Phytochemicals that influence gut microbiota as prophylactics and for the treatment of obesity and inflammatory diseases. Mediators Inflamm. 2018, 2018. [CrossRef]

125. Yuan, X.; Long, Y.; Ji, Z.; Gao, J.; Fu, T.; Yan, M.; Zhang, L.; Su, H.; Zhang, W.; Wen, X.; et al. Green Tea Liquid Consumption Alters the Human Intestinal and Oral Microbiome. Mol. Nutr. Food Res. 2018, 62. [CrossRef] [PubMed]

126. López-Lázaro, M.; Calderón-Montaño, J.M.; Burgos-Morón, E.; Austin, C.A. Green tea constituents (-)-epigallocatechin-3-gallate (EGCG) and gallic acid induce topoisomerase I- and topoisomerase II-DNA complexes in cells mediated by pyrogallol-induced hydrogen peroxide. Mutagenesis 2011, 26, 489-498. [CrossRef]

127. Crascì, L.; Lauro, M.R.; Puglisi, G.; Panico, A. Natural antioxidant polyphenols on inflammation management: Anti-glycation activity vs metalloproteinases inhibition. Crit. Rev. Food Sci. Nutr. 2018, 58, 893-904. [CrossRef]

128. Neukam, K.; Pastor, N.; Cortés, F. Tea flavanols inhibit cell growth and DNA topoisomerase II activity and induce endoreduplication in cultured Chinese hamster cells. Mutat. Res. Genet. Toxicol. Environ. Mutagen. 2008, 654, 8-12. [CrossRef]

129. Duthie, S.J. Epigenetic modifications and human pathologies: Cancer and CVD. In Proceedings of the Nutrition Society; Cambridge University Press: Cambridge, UK, 2011; Volume 70, pp. 47-56.

130. Petermann, E.; Orta, M.L.; Issaeva, N.; Schultz, N.; Helleday, T. Hydroxyurea-Stalled Replication Forks Become Progressively Inactivated and Require Two Different RAD51-Mediated Pathways for Restart and Repair. Mol. Cell 2010, 37, 492-502. [CrossRef]

131. Catala, G.N.; Bestwick, C.S.; Russell, W.R.; Tortora, K.; Giovannelli, L.; Moyer, M.P.; Lendoiro, E.; Duthie, S.J. Folate, genomic stability and colon cancer: The use of single cell gel electrophoresis in assessing the impact of folate in vitro, in vivo and in human biomonitoring. Mutat. Res. - Genet. Toxicol. Environ. Mutagen. 2019, 843, 73-80. [CrossRef] [PubMed]

132. Kirkland, J.B.; Meyer-Ficca, M.L. Niacin. In Advances in Food and Nutrition Research; Academic Press Inc.: Amsterdan, The Netherlands, 2018; Volume 83, pp. 83-149. ISBN 9780128118030.

133. Sheflin, A.M.; Whitney, A.K.; Weir, T.L. Cancer-Promoting Effects of Microbial Dysbiosis. Curr. Oncol. Rep. 2014, 16, 406. [CrossRef]

134. Faïs, T.; Delmas, J.; Barnich, N.; Bonnet, R.; Dalmasso, G. Colibactin: More than a new bacterial toxin. Toxins 2018, $10,151$. [CrossRef] [PubMed]

135. Li, Z.R.; Li, J.; Cai, W.; Lai, J.Y.H.; McKinnie, S.M.K.; Zhang, W.P.; Moore, B.S.; Zhang, W.; Qian, P.Y. Macrocyclic colibactin induces DNA double-strand breaks via copper-mediated oxidative cleavage. Nat. Chem. 2019, 11, 880-889. [CrossRef]

136. Bossuet-Greif, N.; Vignard, J.; Taieb, F.; Mirey, G.; Dubois, D.; Petit, C.; Oswald, E.; Nougayrède, J.P. The colibactin genotoxin generates DNA interstrand cross-links in infected cells. MBio 2018, 9. [CrossRef]

137. Nougayrède, J.-P.; Homburg, S.; Taieb, F.; Boury, M.; Brzuszkiewicz, E.; Gottschalk, G.; Buchrieser, C.; Hacker, J.; Dobrindt, U.; Oswald, E. Escherichia coli Induces DNA Double-Strand Breaks in Eukaryotic Cells. Science 2006, 313, 848-851. [CrossRef]

138. Xue, M.; Wernke, K.M.; Herzon, S.B. Depurination of colibactin-derived interstrand cross-links. Biochemistry 2020, 59, 892-900. [CrossRef]

139. Vizcaino, M.I.; Crawford, J.M. The colibactin warhead crosslinks DNA. Nat. Chem. 2015, 7, 411-417. [CrossRef] [PubMed]

140. Cougnoux, A.; Dalmasso, G.; Martinez, R.; Buc, E.; Delmas, J.; Gibold, L.; Sauvanet, P.; Darcha, C.; Déchelotte, P.; Bonnet, M.; et al. Bacterial genotoxin colibactin promotes colon tumour growth by inducing a senescence-associated secretory phenotype. Gut 2014, 63, 1932-1942. [CrossRef] [PubMed]

141. Liu, Y.; Tavana, O.; Gu, W. p53 modifications: Exquisite decorations of the powerful guardian. J. Mol. Cell Biol. $2019,11,564-577$. [CrossRef]

142. Gong, L.; Sun, Q.; Li, D. Sumoylation in Cellular Senescence and Aging. Curr. Mol. Med. 2017, 16, 871-876. [CrossRef]

143. Leibiger, K.; Schweers, J.M.; Schütz, M. Biogenesis and function of the autotransporter adhesins YadA, intimin and invasin. Int. J. Med. Microbiol. 2019, 309, 331-337. [CrossRef] 
144. Maddocks, O.D.K.; Short, A.J.; Donnenberg, M.S.; Bader, S.; Harrison, D.J. Attaching and Effacing Escherichia coli Downregulate DNA Mismatch Repair Protein In Vitro and Are Associated with Colorectal Adenocarcinomas in Humans. PLoS ONE 2009, 4, e5517. [CrossRef]

145. Maddocks, O.D.K.; Scanlon, K.M.; Donnenberg, M.S. An escherichia coli effector protein promotes host mutation via depletion of DNA mismatch repair proteins. MBio 2013, 4, e5517. [CrossRef] [PubMed]

146. Chang, C.L.; Marra, G.; Chauhan, D.P.; Ha, H.T.; Chang, D.K.; Ricciardiello, L.; Randolph, A.; Carethers, J.M.; Richard Boland, C. Oxidative stress inactivates the human DNA mismatch repair system. Am. J. Physiol. Cell Physiol. 2002, 283, 148-154. [CrossRef] [PubMed]

147. Ge, Z.; Feng, Y.; Ge, L.; Parry, N.; Muthupalani, S.; Fox, J.G. Helicobacter hepaticus cytolethal distending toxin promotes intestinal carcinogenesis in 129Rag2-deficient mice. Cell. Microbiol. 2017, 19, 1-20. [CrossRef] [PubMed]

148. He, Z.; Gharaibeh, R.Z.; Newsome, R.C.; Pope, J.L.; Dougherty, M.W.; Tomkovich, S.; Pons, B.; Mirey, G.; Vignard, J.; Hendrixson, D.R.; et al. Campylobacter jejuni promotes colorectal tumourigenesis through the action of cytolethal distending toxin. Gut 2019, 68, 289-300. [CrossRef]

149. Guerra, L.; Guidi, R.; Frisan, T. Do bacterial genotoxins contribute to chronic inflammation, genomic instability and tumour progression? FEBS J. 2011, 278, 4577-4588. [CrossRef]

150. Frisan, T.; Cortes-Bratti, X.; Chaves-Olarte, E.; Stenerlow, B.; Thelestam, M. The Haemophilus ducreyi cytolethal distending toxin induces DNA double-strand breaks and promotes ATM-dependent activation of RhoA. Cell. Microbiol. 2003, 5, 695-707. [CrossRef]

151. Guerra, L.; Teter, K.; Lilley, B.N.; Stenerlöw, B.; Holmes, R.K.; Ploegh, H.L.; Sandvig, K.; Thelestam, M.; Frisan, T. Cellular internalization of cytolethal distending toxin: A new end to a known pathway. Cell. Microbiol. 2005, 7, 921-934. [CrossRef]

152. Dejea, C.M.; Fathi, P.; Craig, J.M.; Boleij, A.; Taddese, R.; Geis, A.L.; Wu, X.; DeStefano Shields, C.E.; Hechenbleikner, E.M.; Huso, D.L.; et al. Patients with familial adenomatous polyposis harbor colonic biofilms containing tumourigenic bacteria. Science 2018, 359, 592-597. [CrossRef] [PubMed]

153. Goodwin, A.C.; Destefano Shields, C.E.; Wu, S.; Huso, D.L.; Wu, X.Q.; Murray-Stewart, T.R.; Hacker-Prietz, A.; Rabizadeh, S.; Woster, P.M.; Sears, C.L.; et al. Polyamine catabolism contributes to enterotoxigenic Bacteroides fragilis-induced colon tumourigenesis. Proc. Natl. Acad. Sci. USA 2011, 108, 15354-15359. [CrossRef]

154. Sears, C.L.; Geis, A.L.; Housseau, F. Bacteroides fragilis subverts mucosal biology: From symbiont to colon carcinogenesis. J. Clin. Invest. 2014, 124, 4166-4172. [CrossRef]

155. Koi, M.; Okita, Y.M.; Carethers, J. Fusobacterium nucleatum Infection in Colorectal Cancer: Linking Inflammation, DNA Mismatch Repair and Genetic and Epigenetic Alterations. J. Anus Rectum Colon 2018, 2, 37-46. [CrossRef] [PubMed]

156. Rubinstein, M.R.; Wang, X.; Liu, W.; Hao, Y.; Cai, G.; Han, Y.W. Fusobacterium nucleatum Promotes Colorectal Carcinogenesis by Modulating E-Cadherin/ $\beta$-Catenin Signaling via its FadA Adhesin. Cell Host Microbe 2013, 14, 195-206. [CrossRef] [PubMed]

157. Geng, F.; Zhang, Y.; Lu, Z.; Zhang, S.; Pan, Y. Fusobacterium nucleatum Caused DNA Damage and Promoted Cell Proliferation by the Ku70/p53 Pathway in Oral Cancer Cells. DNA Cell Biol. 2020, 39, 144-151. [CrossRef]

158. Beaugerie, L.; Metz, M.; Barbut, F.; Bellaiche, G.; Bouhnik, Y.; Raskine, L.; Nicolas, J.C.; Chatelet, F.P.; Lehn, N.; Petit, J.C. Klebsiella oxytoca as an agent of antibiotic-associated hemorrhagic colitis. Clin. Gastroenterol. Hepatol. 2003, 1, 370-376. [CrossRef]

159. Abbas, A.F.; Al-Saadi, A.G.M.; Alkhudhairy, M.K. Biofilm Formation and Virulence Determinants of Klebsiella oxytoca Clinical Isolates from Patients with Colorectal Cancer. J. Gastrointest. Cancer 2020, 51, 855-860. [CrossRef] [PubMed]

160. Unterhauser, K.; Pöltl, L.; Schneditz, G.; Kienesberger, S.; Glabonjat, R.A.; Kitsera, M.; Pletz, J.; Josa-Prado, F.; Dornisch, E.; Lembacher-Fadum, C.; et al. Klebsiella oxytoca enterotoxins tilimycin and tilivalline have distinct host DNA-damaging and microtubule-stabilizing activities. Proc. Natl. Acad. Sci. USA 2019, 116, 3774-3783. [CrossRef] [PubMed]

161. Hering, N.A.; Fromm, A.; Bücker, R.; Gorkiewicz, G.; Zechner, E.; Högenauer, C.; Fromm, M.; Schulzke, J.D.; Troeger, H. Tilivalline-and tilimycin-independent effects of klebsiella oxytoca on tight junction-mediated intestinal barrier impairment. Int. J. Mol. Sci. 2019, 20, 5595. [CrossRef] [PubMed] 